\title{
Волоконный фемтосекундный лазер с управлением фазой между несущей и огибающей
}

\author{
Н.Н.Головин ${ }^{1}$ Н.И.Дмитриева ${ }^{1}$, К.М. Сабакарь, $\underline{\text { А.К.Дмитриев }}^{1,2, *}$ \\ ${ }^{1}$ Новосибирский государственный технический университет \\ ${ }^{2}$ Институт лазерной физики СО РАН \\ *alexander_dmitriev@ngs.ru
}

DOI:10.31868/RFL2018.160-161

При получении аттосекундных импульсов существенное влияние имеет сдвиг фазы между огибающей и несущей [1]. Использование лазера-гетеродина, частота которого совпадала с низкочастотной, а его вторая гармоника - c высокочастотной областью спектра излучения фемтосекундного лазера позволило устранить сдвиг его частотной гребенки [2]. Это же удалось достичь при использовании акустооптического модулятора [3]. Вместе с тем была продемонстрирована возможность измерения сдвига гребенки частот лазеров с самосинхронизацией мод $\mathrm{c}$ произвольной шириной спектра излучения по смещению полос пропускания интерферометра Фабри-Перо, однако достигнутая погрешность измерения составила величину $10^{-2}$ от частоты повторения [4]. Во всех вышеописанных случаях сдвигфазы между огибающей и несущей имеет произвольную величину.

В настоящей работе предложен метод реализации фемтосекундного излучения без сдвига частотной гребенки в отсутствие лазера-гетеродина при генерации синтезированной последовательности импульсов с требуемой разностью фаз между несущей и огибающей.

При стабилизации частоты повторения и сдвига гребенки частот по стандарту частоты радиодиапазона спектр излучения лазера представляет собой набор эквидистантно расположенных частот, интервал между которыми равен частоте повторения импульсов $f$ присдвиге частотной гребенки лазера $\triangle$

$$
v_{m}=m f+\Delta,
$$

где целое положительное число $m$ - номер моды.
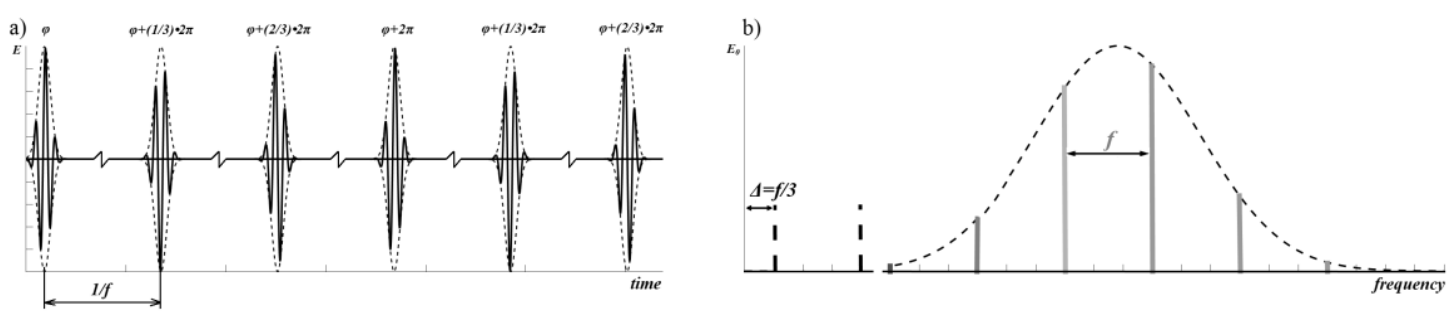

Рис. 1. Последовательность фемтосекундных импульсов (а) и их спектр излучения (b).

На рис. 1а представлена временная последовательность фемтосекундных импульсов при сдвиге частотной гребенки $\Delta=f / 3$. Длительность импульсов $\tau$ ограничена спектральной шириной фемтосекундного излучения $\omega$, а число оптических колебаний в импульсе определяется отношением длительности импульсов $\tau$ к периоду световых колебаний $1 / v_{0}$.

Можно показать, что при выполнении соотношения:

$$
k / q=f / \Delta,
$$


где $k$ и $q$ - целые числа, при выделении из излучения фемтосекундного лазера каждого $k$-ого импульса при соблюдении соотношения (2) получается периодическая последовательность идентичных импульсов на частоте повторения.

$$
F=f l k
$$

При этом сдвиг синтезированной гребенки будет равен нулю, так что спектр излучения представляет набор частот

$$
v_{p}=j F
$$

где $j$ - целое положительное число, а число составляющих спектра в $k$ раз больше по сравнению с излучением на выходе фемтосекундного лазера при неизменной ширине спектра.

Минимальные значения временного, а также пространственного интервала между импульсами в синтезированной последовательности реализуется при $k=3$, когда $\delta= \pm 1 / 3$. На рис. 2а изображено распространение таких фемтосекундных импульсов.
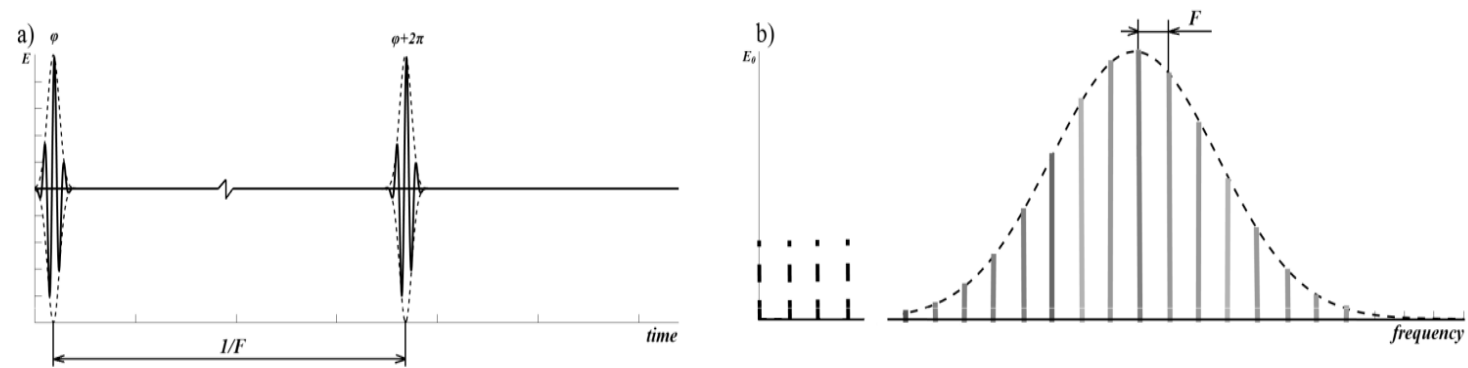

Рис. 2. Периодическая последовательность синтезированных фемтосекундных импульсов (а) и их спектр излучения (b).

Отметим, что в этом случае будет иметь место произвольный сдвиг фазы несущей относительно огибающей.

Из всех возможных последовательностей импульсов сдвиг фазы несущей относительно огибающей может селектироваться с дискретностью $2 \pi / k$ от минимального значения $\varphi_{\min } \leq 2 \pi / k$ до $2 \pi$.

Эксперименты были выполнены с помощью волоконного фемтосекундного лазера MenloSystems FC1500-250WGc частотой повторения импульсов $f=250$ МГц. Эта частота синхронизировалась с частотой 10 МГц прецизионного генератора StanfordSG384. Этот же генератор мог задавать сдвиг гребенки на различных частотах $F$. Максимальное значение частоты $F$ составляло 62.5 МГц. Сигнал на частоте $F$ через фазовращатель поступал на импульсный генератор, который управлял модулятором интенсивности, на выходе которого синтезировалась последовательность идентичных фемтосекундных импульсов с частотой повторения $F$. Фазовращатель позволял выделять последовательность импульсов с заданной разностью фаз между несущей и огибающей.

Работа выполнена при финансовой поддержке гранта Министерства образования и науки РФ в рамках базовой части государственного задания №3.6835.2017/8.9 и гранта РФФИ № 18-02-00316.

\section{Литература}

[1] BohanA.D., AntoineP., etal., Phys. Rev.Lett. 81, 1837 (1998)/

[2] UdemTh., Reichert J. et al.Phys. Rev. Lett., 82, 3568 (1999).

[3] David J. Jones, Scott A. Diddams, tt al., Science, 82635 (2000).

[4] Баснак Д.В., Бикмухаметов К.А., и др., Квантоваяэлектроника, т.42(1), 71, (2012) 